\title{
Pancreatic and Gastric
} Plasmacytoma Presenting with Obstructive Jaundice, Diagnosed with Endoscopic Ultrasound-Guided Fine Needle Aspiration

\author{
Manmeet S. Padda ${ }^{a}$ Tiffani Milless ${ }^{b}$ \\ Adebowale J. Adeniran ${ }^{c}$ Sepi Mahootic Harry R. Aslanian ${ }^{a}$ \\ aDepartment of Internal Medicine, Division of Digestive Diseases, and \\ Departments of ${ }^{\mathrm{b} P a t h o l o g y}$ and ${ }^{\mathrm{C} C y t o l o g y}$, Yale University School of Medicine, \\ New Haven, Conn., USA
}

\section{Key Words}

Pancreatic plasmacytoma - Jaundice - Endoscopic ultrasound-guided fine needle aspiration

\begin{abstract}
Pancreatic plasmacytoma is a rare disorder which may present with obstructive jaundice. Only eighteen cases have been reported in the English language literature. We present the first case of pancreatic plasmacytoma and gastric plasmacytoma diagnosed with endoscopic ultrasound-guided fine needle aspiration (EUS-FNA). A 75-year-old male with a known history of multiple myeloma presented with obstructive jaundice and a pancreatic mass. A concomitant gastric mass due to gastric plasmacytoma was seen. The diagnosis was established via EUS-FNA of the pancreatic mass. Pancreatic plasmacytoma should be suspected in patients with a history of myeloma. EUS-FNA is a safe and effective modality in the diagnosis of pancreatic plasmacytoma. Radiation therapy should be the first-line of therapy in treating pancreatic plasmacytomas.
\end{abstract}

\section{Introduction}

Extramedullary plasmacytomas consist of neoplastic plasma cell proliferation that occurs outside the bone marrow. Extraskeletal plasmacytomas are infrequent, occurring in fewer than 5\% of plasma cell neoplasms [1]. Pancreatic plasmacytomas are rare, with only eighteen cases identified in the English language literature. Endoscopic ultrasound 


\begin{tabular}{r|l|l|l}
$\begin{array}{r}\text { Case Reports in } \\
\text { Gastruanteriology }\end{array}$ & $\begin{array}{l}\text { Case Rep Gastroenterol 2010;4:410-415 } \\
\text { DOI: 10.1159/000321050 }\end{array}$ & $\begin{array}{l}\text { Published online: } \\
\text { September 28, 2010 }\end{array}$ & $\begin{array}{l}\text { O 2010 S. Karger AG, Basel } \\
\text { ISSN 1662-0631 } \\
\text { www.karger.com/crg }\end{array}$ \\
\hline
\end{tabular}

provides detailed imaging of the pancreas and accurate fine needle aspiration tissue sampling [2]. We describe a case of concomitant pancreatic and gastric plasmacytoma diagnosed with endoscopic ultrasound-guided fine needle aspiration (EUS-FNA) of the pancreas and endoscopic biopsy of the stomach in a patient with multiple myeloma.

\section{Case Report}

A 75-year-old male with a 10-year history of multiple myeloma treated with chemotherapy and radiation therapy presented with three weeks of progressive fatigue and jaundice. His past medical history included coronary artery disease, peripheral neuropathy and deep venous thrombosis. Physical exam revealed icteric sclerae and a normal abdominal examination. Laboratory studies revealed anemia with a hemoglobin of $8.2 \mathrm{~g} / \mathrm{dl}$ and an obstructive liver enzyme pattern with a total bilirubin of $6.9 \mathrm{mg} / \mathrm{dl}$, alkaline phosphatase of $347 \mathrm{U} / \mathrm{l}$ and ALT of $528 \mathrm{U} / \mathrm{l}$. Abdominal ultrasound identified a $5.3 \mathrm{~cm}$ focal lesion arising from the head/proximal body of the pancreas, with a lobular contour and inhomogenous texture. The common bile duct was dilated to $2 \mathrm{~cm}$. Fascial and maxillary computed tomography scan was unremarkable.

Upper endoscopy (esophagogastroduodenoscopy) identified a $4 \mathrm{~cm}$ gastric mass with a large adherent blood clot, located in the proximal body along the greater curvature, with overlying ulceration (fig. 1). Forceps biopsies were obtained from the edge of the gastric mass. Pathology revealed reactive gastric glands surrounded by a dense, diffuse infiltrate of plasmacytoid cells (fig. 2). These cells were characterized by a moderate amount of amphophilic cytoplasm and eccentric nuclei with scattered nuclear pleomorphism. Although many cells displayed a mature plasma cell phenotype, others appeared immature. The differential diagnosis included lymphocytic gastritis related to Helicobacter pylori, plasma cell-rich mucosa-associated lymphoid tissue (MALT)-type lymphoma, and plasmacytoma. Immunostain for Helicobacter species was negative, Mum1 (a myeloma-associated oncogene), kappa light chain and CD138 immunostains were positive, while lambda light chain stains were negative, consistent with involvement by the patient's multiple myeloma.

Linear endoscopic ultrasound examination (GFUCT-140, Olympus America, Center Valley, Pa., USA) identified a $4 \times 5 \mathrm{~cm}$ hypoechoic, heterogenous mass in the head of the pancreas obstructing the bile duct (fig. 3 ). The bile duct measured $2 \mathrm{~cm}$ with some sludge within the duct. The pancreatic duct was not obstructed by the mass (measuring $1.8 \mathrm{~mm}$ in the body) and the pancreatic parenchyma in the body and tail was normal. No enlarged peripancreatic or celiac lymph nodes were seen. The $5 \times 4 \mathrm{~cm}$ gastric mass had a similar sonographic appearance and was seen to abut the spleen. EUS-FNA of the pancreatic and gastric mass was performed. Both sites revealed a predominant monomorphic population of plasma cells, which were dispersed as single cells. The cells had round to oval eccentric nuclei, nuclear membrane irregularity, occasional prominent nucleoli and a fine to coarsely clumped chromatin pattern. The cytoplasm was abundant and basophilic, with a perinuclear clear zone. These cytologic features were consistent with plasmacytoma (ig. 4 ).

The aspirated material obtained from the head of the pancreas was also sent for flow cytometry. Flow cytometry showed more than $60 \%$ of the cells to be positive for CD $45 \mathrm{dim}$, CD38, and were cyto-kappa-restricted, confirming the diagnosis of plasmacytoma. The patient was treated with radiation therapy, which resulted in improvement of liver function tests. Six months later his liver enzymes remained normal and repeat imaging studies of the pancreas showed resolution of the pancreatic plasmacytoma.

\section{Discussion}

Plasmacytoma is an immunoproliferative monoclonal disorder of plasma cells that usually affects the bone marrow. Extramedullary plasmacytomas involve soft tissue organs outside the bone marrow and represent 3-4\% of all plasma cell neoplasms. Plasmacytomas may be primary (in the absence of multiple myeloma of the bone marrow) or secondary (in the presence of multiple myeloma of the bone marrow) [3]. 


\begin{tabular}{r|l|l|l}
$\begin{array}{r}\text { Case Reports in } \\
\text { Gastruenterology }\end{array}$ & $\begin{array}{l}\text { Case Rep Gastroenterol 2010;4:410-415 } \\
\text { DOI: 10.1159/000321050 }\end{array}$ & $\begin{array}{l}\text { Published online: } \\
\text { September 28, 2010 }\end{array}$ & $\begin{array}{l}\text { O 2010 S. Karger AG, Basel } \\
\text { ISSN 1662-0631 } \\
\text { www.karger.com/crg }\end{array}$ \\
\hline
\end{tabular}

Plasmacytomas are composed of plasma cells of variable maturity, which are histologically analogous to those seen in multiple myeloma. The median age of presentation of extramedullary plasmacytomas is 55 years ( 10 years younger than patients with multiple myeloma) and the majority (three-fourths) are male [4]. The upper respiratory tract (oronasopharynx and paranasal sinuses) is the most common site (80\%) of extramedullary plasmacytomas [5]. Approximately $10 \%$ of extramedullary plasmacytomas occur in the gastrointestinal tract, the stomach being the most frequent site [6].

The diagnosis of an extramedullary plasmacytoma depends on the demonstration of a monoclonal plasma cell tumor outside the bone marrow. Poorly differentiated pancreatic neoplasms and lymphoma may be difficult to differentiate from plasmacytomas; immunohistochemistry and flow cytometry play key roles in diagnosis. In our case, immunohistochemistry was performed on an endoscopic mucosal biopsy of the stomach and flow cytometry on EUS-FNA of the pancreas. In rare cases, extramedullary plasmacytoma may represent a marginal zone B-cell lymphoma that has undergone an extensive degree of plasmacytic differentiation, which signifies a worse prognosis [7]. Extramedullary gastric plasmacytomas may further cause a diagnostic dilemma in the differentiation from MALT-type lymphoma. The absence of morphologic criteria of gastric MALT including centrocyte-like cells, lymphoepithelial lesions, reactive follicles and absence of B-lymphocyte antigens (CD45 and CD20) helps in the differentiation [8].

It is very difficult to radiologically differentiate extramedullary plasmacytoma of the pancreas from other pancreatic tumors, especially those which show enhancement with intravenous contrast such as endocrine cell tumors and acinar cell neoplasms [9]. Sonographically, pancreatic plasmacytomas appear as hypoechoic, homogenous masses, well demarcated from the surrounding normal pancreatic parenchyma. This is the first case report of EUS-FNA confirming the diagnosis of a pancreas plasmacytoma. Diagnosis has been obtained in prior reports via percutaneous biopsy or laparotomy $[3,10]$. As demonstrated in this case, EUS-FNA may also provide adequate material for flow cytometry analysis [11].

The management of patients with extramedullary plasmacytoma may include radiation therapy, surgery, or combination therapy (surgery and/or chemotherapy or radiation) $[12,13]$. Plasma cell tumors are highly sensitive to radiation therapy. Solitary plasmacytoma of the tail of the pancreas can also be managed by distal pancreatectomy in good surgical candidates [14]. Patients with extramedullary plasmactyoma who had combined surgery and radiation therapy had a median survival 25 years greater than those who had only surgical intervention (13 years) or only radiation therapy (12 years) [12].

\section{Conclusion}

In summary, we report a rare case of concomitant extramedullary gastric and pancreatic plasmacytoma which is the first report of pancreatic plasmacytoma diagnosed with EUS-FNA. Extramedullary plasmacytoma should be considered in the differential diagnosis in patients with multiple myeloma presenting with a pancreatic mass and/or obstructive jaundice. 


\begin{tabular}{r|l|l|l}
$\begin{array}{r}\text { Case Reports in } \\
\text { Gastruenterology }\end{array}$ & $\begin{array}{l}\text { Case Rep Gastroenterol 2010;4:410-415 } \\
\text { DOI: 10.1159/000321050 }\end{array}$ & $\begin{array}{l}\text { Published online: } \\
\text { September 28, 2010 }\end{array}$ & $\begin{array}{l}\text { O 2010 S. Karger AG, Basel } \\
\text { ISSN 1662-0631 } \\
\text { www.karger.com/crg }\end{array}$ \\
\hline
\end{tabular}

\section{Disclosure Statement}

All the authors declare that they have no conflict of interest.

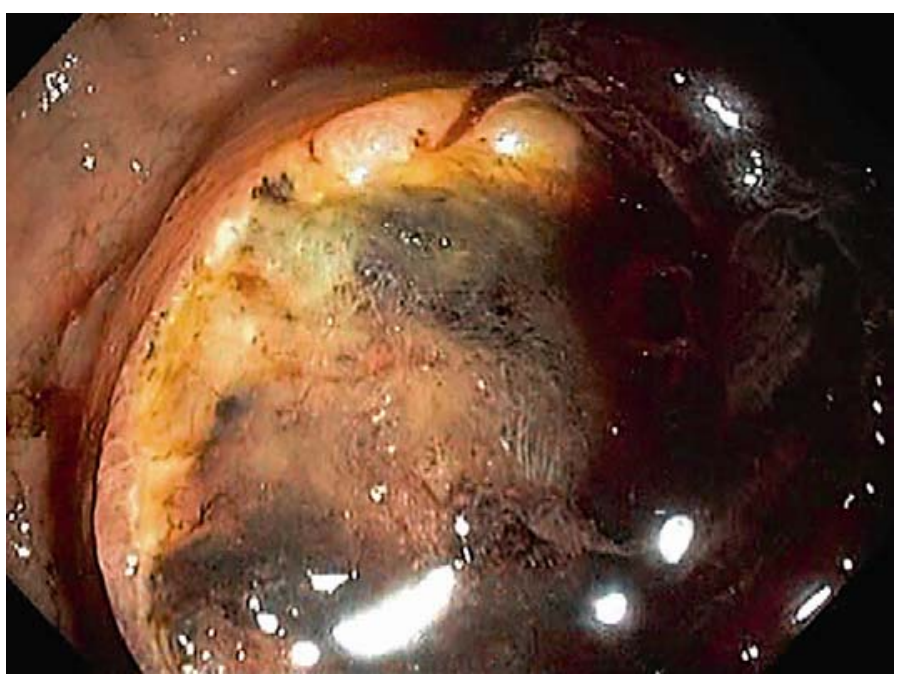

Fig. 1. Endoscopic image of the ulcerated, raised gastric mass with adherent blood clot.

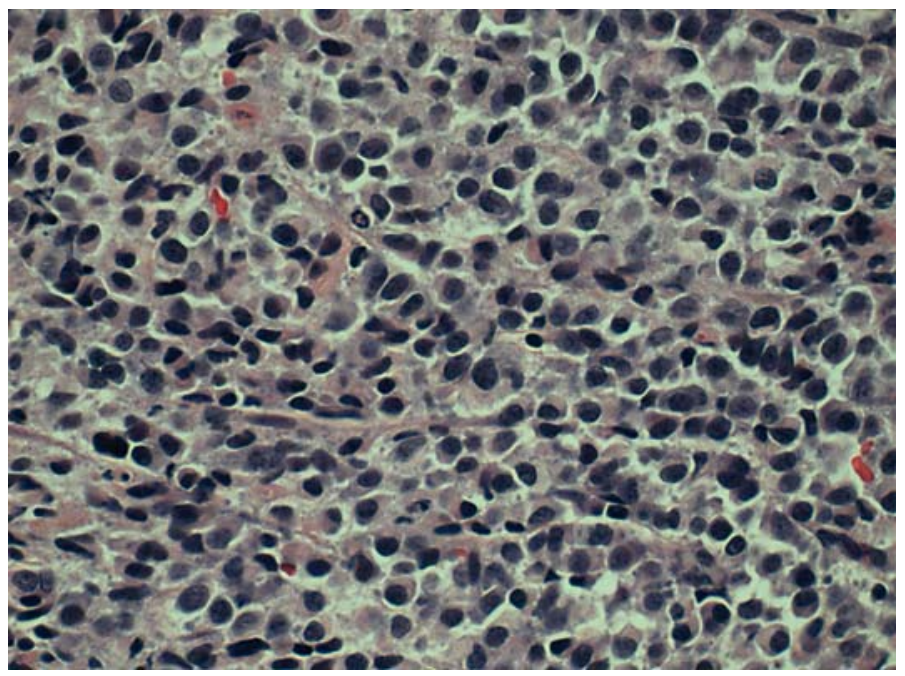

Fig. 2. Gastric biopsy (H\&E, high power magnification) with a diffuse infiltrate of plasmacytoid cells. 


\begin{tabular}{r|l|l|l}
$\begin{array}{r}\text { Case Reports in } \\
\text { Gastruanterology }\end{array}$ & $\begin{array}{l}\text { Case Rep Gastroenterol 2010;4:410-415 } \\
\text { DOl: 10.1159/000321050 }\end{array}$ & $\begin{array}{l}\text { Published online: } \\
\text { September 28, 2010 }\end{array}$ & $\begin{array}{l}\text { I 2010 S. Karger AG, Basel } \\
\text { ISSN 1662-0631 } \\
\text { www.karger.com/crg }\end{array}$ \\
\hline
\end{tabular}

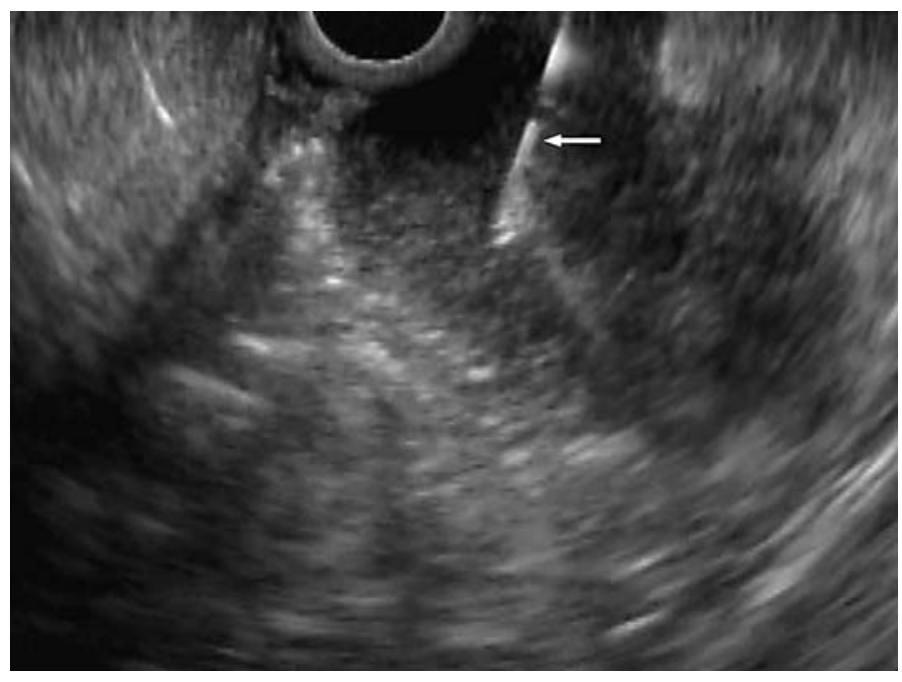

Fig. 3. Endoscopic ultrasound image of a hypoechoic mass in the head of the pancreas with FNA needle within the mass (arrow).

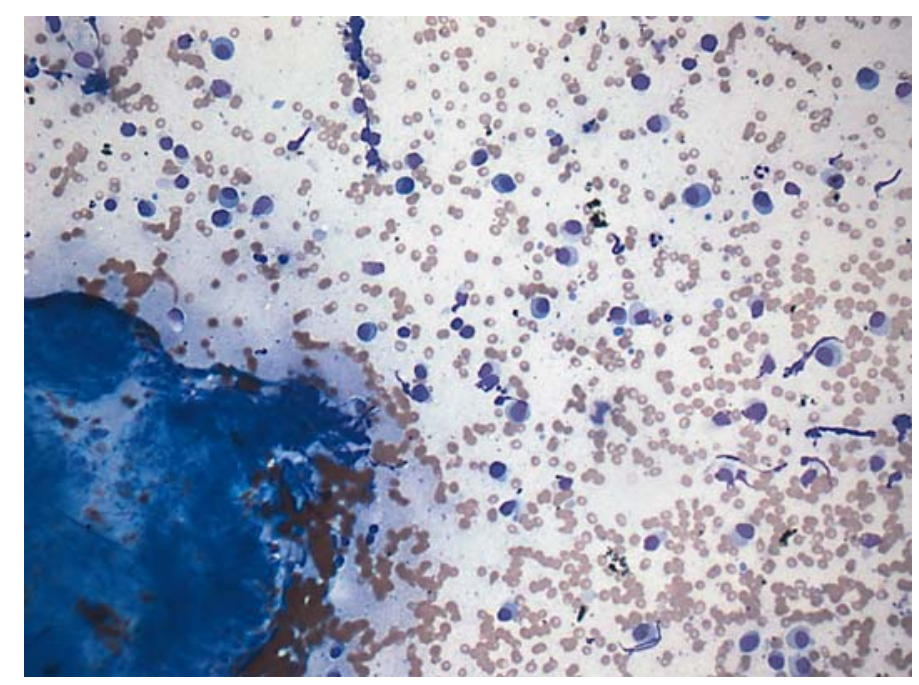

Fig. 4. EUS-FNA cytology of the pancreatic mass (PAP stain) showing a predominant monomorphic population of plasma cells.

\section{References}

1 Hameed A, Ryan M, Kamel D, Vusirikala M: Plasmacytoma of the pancreas and pelvis: a case report. Lab Hematol 2008;14:10-11.

2 Savides TJ, Donohue M, Hunt G, Al-Haddad M, Aslanian H, Ben-Menachem T, Chen VK, Coyle W, Deutsch J, DeWitt J, Dhawan M, Eckardt A, Eloubeidi M, Esker A, Gordon SR, Gress F, Ikenberry S, Joyce AM, Klapman J, Lo S, Maluf-Filho F, Nickl N, Singh V, Wills J, Behling C: EUS-guided FNA diagnostic yield of malignancy in solid pancreatic masses: a benchmark for quality performance measurement. Gastrointest Endosc 2007;66:277-282.

3 Hirata S, Yamaguchi K, Bandai S, Izumo A, Chijiiwa K, Tanaka M: Secondary extramedullary plasmacytoma involving the pancreas. J Hepatobiliary Pancreat Surg 2002;9:111-115. 
4 Tsang RW, Gospodarowicz MK, Pintilie M, Bezjak A, Wells W, Hodgson DC, Stewart AK: Solitary plasmacytoma treated with radiotherapy: impact of tumor size on outcome. Int J Radiat Oncol Biol Phys 2001;50:113-120.

5 Bachar G, Goldstein D, Brown D, Tsang R, Lockwood G, Perez-Ordonez B, Irish J: Solitary extramedullary plasmacytoma of the head and neck - long-term outcome analysis of 68 cases. Head Neck 2008;30:1012-1019.

6 Nolan KD, Mone MC, Nelson EW: Plasma cell neoplasms. Review of disease progression and report of a new variant. Surg Oncol 2005;14:85-90.

7 Hussong JW, Perkins SL, Schnitzer B, Hargreaves H, Frizzera G: Extramedullary plasmacytoma. A form of marginal zone cell lymphoma? Am J Clin Pathol 1999;111:111-116.

8 Lin BT, Weiss LM: Primary plasmacytoma of lymph nodes. Hum Pathol 1997;28:1083-1090.

9 Wilson TE, Korobkin M, Francis IR: Pancreatic plasmacytoma: CT findings. AJR Am J Roentgenol 1989;152:1227-1228.

10 Dodd LG, Evans DB, Symmans F, Katz RL: Fine-needle aspiration of pancreatic extramedullary plasmacytoma: possible confusion with islet cell tumor. Diagn Cytopathol 1994;10:371-374; discussion 374-375.

11 Ribeiro A, Vazquez-Sequeiros E, Wiersema LM, Wang KK, Clain JE, Wiersema MJ: EUS-guided fine-needle aspiration combined with flow cytometry and immunocytochemistry in the diagnosis of lymphoma. Gastrointest Endosc 2001;53:485-491.

12 Alexiou C, Kau RJ, Dietzfelbinger H, Kremer M, Spiess JC, Schratzenstaller B, Arnold W: Extramedullary plasmacytoma: tumor occurrence and therapeutic concepts. Cancer 1999;85:2305-2314.

13 Ishido T, Mori N: Primary gastric plasmacytoma: a morphological and immunohistochemical study of five cases. Am J Gastroenterol 1992;87:875-878.

14 Dimopoulos MA, Kiamouris C, Moulopoulos LA: Solitary plasmacytoma of bone and extramedullary plasmacytoma. Hematol Oncol Clin North Am 1999;13:1249-1257. 